\section{Estimating Forage Production from Shrub Ring Widths in Hot Creek Valley, Nevada ${ }^{1,2}$}

\section{J. BARRY DAVIS 3 , PAUL T. TUELLER, AND ALLEN D. BRUNER}

Graduate Fellow, Associate Range Ecologist, and Research Associate, Renewable Resources Center, University of Nevada, Reno.

\section{Highlight}

Floristic and soil factors on 60 sites in the shadscale and sagebrush zone in Hot Creek Valley, Nevada were sampled to derive one or more equations for estimating production on those sites. The factors were analyzed by an all possible correlation followed by stepwise regression with production as the dependent variable. Many of the factors correlated significantly with production, but widths of growth rings of shrubs accounted for most of the variation in production. Thus, ring widths of big sagebrush, bud sagebrush, shadscale, common winterfat, and spiny hopsage were used to derive regression equations to estimate forage production. Big sagebrush and shadscale ring widths varied exponentially with production, while a linear relationship expressed the regression of production on ring widths for the other shrubs. The linear regression probably represents only a portion of the complete curve. The methods of collection and analysis of shrub rings to derive production estimation equations could probably be extended to other areas within the Great Basin.

Forage productivity, with reservations due to varying stages of plant succession, has been used extensively as an index of site quality. Productivity

\footnotetext{
${ }^{1}$ Received August 18, 1971.

2 The authors wish to acknowledge support of this study by the USAEC, Nevada Operations Office, Life Sciences Branch, AEC Contract AT(26-1)-409.

${ }^{3}$ Now Forester, U.S. Forest Service, Ephraim, Utah.
}

is a function of at least climate, vegetation, soil, time, and biota. We need to relate production, as the dependent variable, to site characteristics in developing production estimation equations.

Carmean (1954) determined the effects of soil, climate, and topography on the growth of Douglasfir [Pseudotsuga Menziesii (Mirb.) Franco] in southwestern Washington. He linked site quality with specific site factors, and developed prediction equations of the general form,

$$
\mathrm{Y}=\mathrm{f}\left(\mathrm{X}_{1} \mathrm{X}_{2} \ldots \mathrm{X}_{\mathrm{n}}\right)
$$

which expressed tree height in terms of tree age and associated environmental conditions. Carmean found that site quality for Douglas-fir increased with an increase in depth to substratum, decreased with an increase in percent of gravel in the soil profile, and decreased as soil compaction increased.

Hulett et al. (1969) found that total forage production and total basal area on clay upland range sites in western Kansas increased as the combined depth of the A and B horizon increased. Doolittle (1957) noted that depth of the A horizon accounted for $91 \%$ of the variation in the site index of scarlet and black oak in the southern Appalachians.

Soil texture, like depth, has been a useful index to productivity. Medin (1960) found that the production of mountainmahogany (Cercocarpus montanus Raf.) varied directly with the clay content of the A horizon and soil depth.

In the last few years, a great deal of work in the western United States has been completed relating production and precipitation. One of the most complete studies relating precipitation to yield was done by Sneva and Hyder (1962) in castern Oregon. They found that in a single growing season herbage production depended largely upon the amount of precipitation received immediately before and during the growing season. Yield indices were plotted 
over respective precipitation indices and fitted by linear regression. Blaisdell (1958) observed a similar correlation between precipitation and subsequent herbage yield along the upper Snake River. In western Kansas, forage production on clay upland range sites was related to seasonal precipitation, with May and June precipitation the most influential determinant of total forage production (Hulett et al. 1969).

Floristic qualities by themselves have not been, until quite recently in the United States, related to site production. Kinsinger and Strickler (1961) in Nevada noted significant correlations between the production and ground cover of winterfat [Eurotia lanata (Pursh) Moq.]. Crown diameters of Utah juniper [Juniperous utahensis (Engelm) Lemm.] were used successfully by Mason and Hutchings (1967) to estimate the total foliage production of juniper. Groebel et al. (1958) observed a definite correlation between plant cover estimate and herbage production in shadscale [Atriplex confertifolia (Torr. \& Frem.) Wats.] and winterfat when these plants occurred in pure stands. Tower (1970) found significant correlations between the cover, density, and production in Nevada of antelope bitterbrush [Purshia tridentata (Pursh) DC.].

McGinnies (1967) reported good correlations between herbage production and radial increment of growth rings. He compared production of crested wheatgrass plantings with the annual growth increments of trees and shrubs surrounding the seedings.

DieHert (1938) in his description of the stem structure of big sagebrush (Artemisia tridentata Nutt.) describes the growth rings as annual rings. Ferguson (1964) found that the width of annual rings of big sagebrush were strongly correlated to winter precipitation in Arizona.

\section{Experimental Area and Procedures}

The Hot Creek study area is located within the Great Basin Section of the Basin and Range Province described by Hunt (1967). The study area is at the base of Morey Peak, about 70 miles northeast of Tonopah, and within the Atomic Energy Commission's Central Nevada Supplement Test Site.

The elevation of the area varies from 5,440 feet to 6,500 feet with an average elevation of 5,705 feet. The past annual 20-year average precipitation for the Rattlesnake Highway station (elev. 5,910 feet) is 5.84 inches and the average temperature is $51 \mathrm{~F}$.

The plant associations were defined on the basis of dominant shrubs in the overstory and dominant grasses or forbs in the understory. Once the plant associations were defined and delineated, a macroplot procedure was used to collect vegetation and ground cover information excluding production. Each plot was selected on the basis of uniformity, not only in regard to floristic composition, but also with regard to soil and relief. Vegetation data were collected from four to fourteen $15 \times 30 \mathrm{~m}$ macroplots within each plant association. Ten, $15 \mathrm{~m}$ transects were located perpendicular to the $30 \mathrm{~m}$ baseline and up slope where the slope could be de- termined visually. Frequency, vegetative cover, and ground cover characteristics were determined along the $15 \mathrm{~m}$ transects. Frequency percentages were determined as rooted presence in 100 microplots per macroplot. Cover, as used here, is the basal area of the forbs and grasses plus the shrub crown cover. The ground cover was classified into one of the following categories: (1) plant basal area, (2) litter, (3) bare soil, (4) gravel $(2 \mathrm{~mm}$ to $7 \mathrm{~cm}$ ), and (5) stone (greater than $7 \mathrm{~cm}$ diameter).

Productivity of grasses, forbs, and shrubs was determined from clippings on twenty $9.6 \mathrm{ft}^{2}$ plots located along a line through the center of each macroplot. Grasses and forbs were clipped at ground level. Only the current year's growth of the shrubs was removed. Clipping was completed each of 2 years after all of the major plant species had completed growth. 'This occurred during late August the first year and the first of September the second year. The plant material was oven-dried and weighed to the nearest gram. These weights were then converted to pounds per acre.

Within each macroplot a soil pit was dug to at lcast a 48-inch depth or until a duripan or bedrock was encountered. Soil characteristics such as $\mathrm{pH}$, depth of horizon, color, and position on slope were coded so that differences in each property could be expressed quantitatively and used to determine their relationship to plant production on each macroplot. A soil sample was obtained from each soil horizon and particle size distribution was determined using a hydrometer method (Bouyoucos, 1936). The available water-holding capacity was estimated from soil texture and depth of soil (Anon., 1968). Elevation, slope, microrelief, location on the slope and aspect were recorded for each macroplot.

Stems of each shrub species were collected and ring widths from ten shrubs of each species were measured for every macroplot. Shrub rings measured were those from shrubs that had 25 to 35 growth rings. After sanding and polishing the cross sections, ring widths were measured to the nearest $0.01 \mathrm{~mm}$ with a Craighead-Douglas dendrochronograph. Ring widths were measured along two radii on each cross-section and averaged for each year. Shrub cross-sections were collected again the second year when the macroplots were clipped for production.

All growth rings were compared with the known annual rings of big sagebrush to determine if any correlation existed. A close correlation might suggest that the rings from species other than big sagebrush were annual rings.

\section{Results and Discussion}

To determine the effect of all of the factors on the production within 50 macroplots, each of 60 soil and floristic factors were correlated with all of the remaining factors for all macroplots (Table 1 ). Using a step-wise regression program (Dixon, 1970), those variables with the highest partial correlation coefficients with production were combined to create a multiple regression equation having the least possible standard error. Even though some of the simple coefficients were highly significant, the most significant accounted for only $16 \%$ of the variation in the annual forage production. The standard error of the resulting equation was $25 \%$ of the mean and too large to estimate forage production.

The shrub rings would be expected to corre- 
Table 1. Correlation coefficients of floristic and soil factors in Hot Creek Valley which in 1969 wcre significantly correlated with forage production.

\begin{tabular}{|c|c|c|c|}
\hline Factor & $\mathrm{r}^{1}$ & Factor & $\mathrm{r}$ \\
\hline Aspect & .379 & Avail. water-holding & \\
\hline Percent cover & .256 & $\begin{array}{l}\text { capacity in the effec- } \\
\text { tive rooting depth }\end{array}$ & -.387 \\
\hline $\begin{array}{l}\text { Number of species } \\
\text { in macroplot }\end{array}$ & .438 & Effective rooting depth & .340 \\
\hline $\begin{array}{l}\text { Ten year average } \\
\text { ring width }\end{array}$ & .233 & $\begin{array}{l}\text { Strength Structure ' } \mathrm{B} \text { ' } \\
\text { Silt \& clay in the B }\end{array}$ & -.554 \\
\hline 1969 ring width & .489 & & .235 \\
\hline $\begin{array}{l}\text { Available water- } \\
\text { holding capacity } \\
\text { A \& B horizons }\end{array}$ & .412 & $\begin{array}{l}\text { Depth } B \times \text { texture } \\
\text { Total depth A \& B } \times \\
\text { texture }\end{array}$ & .425 \\
\hline Clay B-horizon & .216 & Depth to effervescence & .218 \\
\hline $\begin{array}{l}\text { Percent gravel } \\
\text { A \& B horizons }\end{array}$ & -.271 & Percent basal area & .430 \\
\hline
\end{tabular}

\footnotetext{
${ }^{1}$ Significance of the correlation coefficients.

$\mathrm{r}=.211 \mathrm{P}<.1$

$\mathrm{r}=.250 \mathrm{P}<.05$

$\mathrm{r}=.324 \mathrm{P}<.01$
}

late poorly because spiny hopsage [Grayia spinosa (Hook.) Moq.], big sagebrush, bud sagebrush (Artemisia spinescens D.C. Eat.), and shadscale are grouped together as one variable. This grouping was necessary because none of the shrubs are found on all of the macroplots. Big sagebrush, which is the most widely distributed shrub, is located on only one-third of the macroplots.

There was no correlation between ring widths of big sagebrush and those species belonging to the
Chenopodiaceae. Evidence suggests that these species may not produce annual rings (Eames and MacDaniels, 1925; Plummer ${ }^{4}$. The ring widths on the cheopods were complacent. Ring width differences within a site normally varied no more than 20 percent. However, from site to site there was as much as $600 \%$ difference. Thus, we feel that even though the ring widths may not necessarily be annual increments, they definitely reflect site differences.

To reduce the variance, the macroplots were grouped into five plant associations (Table 2) and analyzed with an all-possible correlation analysis followed by the step-wise regression. Shrub rings accounted for an average of $90 \%$ of the reduction in the standard error. 'Therefore, the estimation equations could be greatly simplified, without reducing their precision significantly, if ring widths only were used as the independent variable. Then simple linear and curvilinear regressions were calculated with production as the dependent variable.

The relationship between production and width of big sagebrush and shadscale growth rings appear to be exponential. The highest correlation coefficient was obtained by relating the logarithms of both production and ring width (Fig. 1). The confidence belt shown is for the mean and not for individual ring width observations. Figure 2 illustrates examples of shrub rings used in estimating production.

In contrast, linear equations adequately describe the relation between yield and ring widths of winterfat, spiny hopsage, and bud sagebrush. This

${ }^{4}$ Personal communications with A. Perry Plummer, 1971.

Table 2. Production estimation equations for Hot Creek Valley with ring widths of shrubs as the independent variables.

\begin{tabular}{|c|c|c|c|c|}
\hline Shrubs & Location & Equation & $\mathrm{r}$ and $\mathrm{r}^{2}$ & $\begin{array}{c}\text { Significance } \\
\text { level }\end{array}$ \\
\hline Winterfat & $\begin{array}{l}\text { All plant associations where } \\
\text { found }^{1}\end{array}$ & $\mathrm{Y}=1620 \mathrm{X}_{1}-129.22$ & $\begin{array}{l}\mathrm{r}=.939 \\
\mathrm{r}^{2}=.882\end{array}$ & .001 level \\
\hline Shadscale & Atco Hija plant associations & 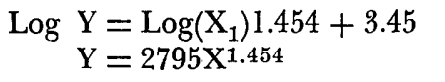 & $\begin{array}{l}\mathrm{r}=.933 \\
\mathrm{r}^{2}=.870\end{array}$ & .001 level \\
\hline Bud sagebrush & Atco Hija plant associations & $Y=756.43+39.33 X_{1}$ & $\begin{array}{l}\mathrm{r}=.615 \\
\mathrm{r}^{2}=.378\end{array}$ & .01 level \\
\hline Spiny hopsage & $\begin{array}{l}\text { All plant associations where } \\
\text { found } 1\end{array}$ & $Y=1328.69-76.41 X_{1}$ & $\begin{array}{l}\mathrm{r}=.832 \\
\mathrm{r}^{2}=.693\end{array}$ & .001 level \\
\hline Big sagebrush & Artr Hija plant associations & $\begin{aligned} \log Y & =\log \left(X_{1}\right) 1.5196+2.15 \\
Y & =346 X_{1}^{1.5196}\end{aligned}$ & $\begin{array}{l}\mathrm{r}=.823 \\
\mathrm{r}^{2}=.678\end{array}$ & .001 level \\
\hline Big sagebrush & Artr Grsp Orhy associations & $\begin{aligned} \log Y & =\log \left(X_{1}\right) 1.55+2.55 \\
Y & =354 X_{1}^{1.55}\end{aligned}$ & $\begin{array}{l}\mathrm{r}=.972 \\
\mathrm{r}^{2}=.945\end{array}$ & .001 level \\
\hline
\end{tabular}

${ }^{1}$ Five plant associations were defined in this study: Atco Hija, Artr Hija, Artr Grsp Orhy, Chvi Hija, and Eula Atco Hagl. Symbols used are: Atco $=$ shadscale, Hija $=$ galleta (Hilaria jamesii), Artr $=$ big sagebrush, Grsp $=$ spiny hopsage, Orhy $=$ Indian ricegrass (Oryzopsis hymenoides), Chvi = yellowbrush (Chrysothamnus viscidiflorus), Eula $=$ winterfat, and Hagl $=\mathrm{Halogeton}$ (Halogeton glomeratus). 


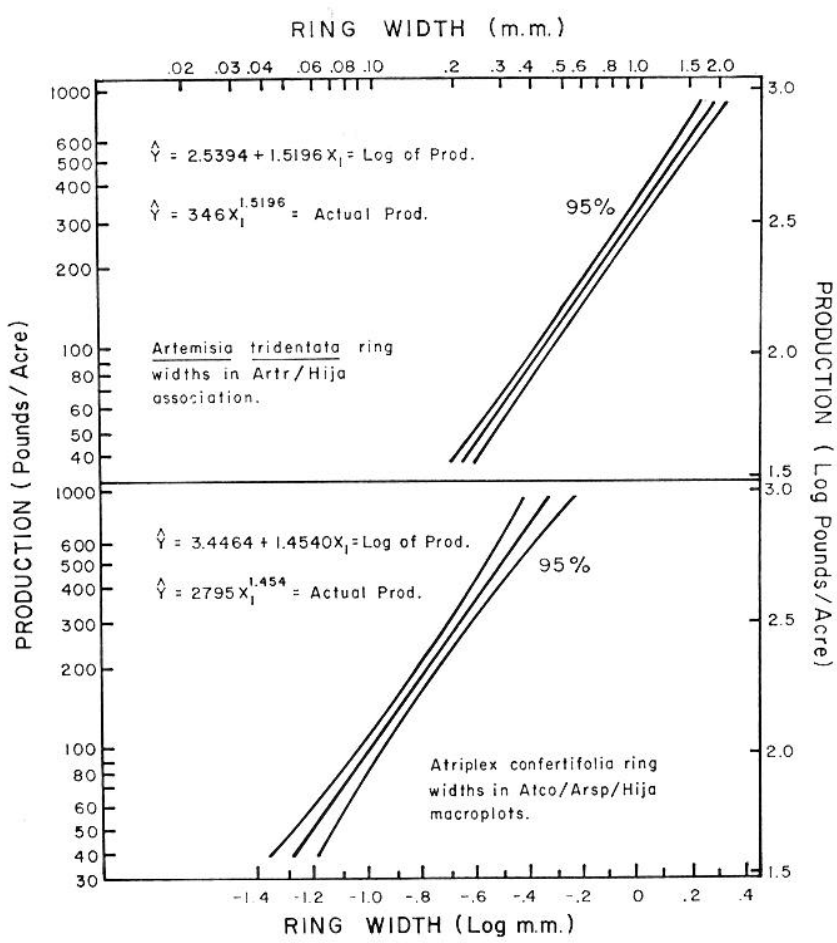

FIG. 1. Total vegetation production in relation to ring widths of big sagebrush (Artemisia tridentata) and shadscale (Atriplex confertifolia). The confidence limits indicate the limits within which the true mean of $\mathrm{Y}$ for a given $\mathrm{X}$ will be.

regression probably represents only a linear portion of the complete curve (Fig. 1).

The method used to derive estimation equations could possibly be extended to other plant associa- tions in the Intermountain Region. To eliminate the problem caused by younger plants with larger rings, individual ring widths should be standardized by dividing each ring width by the average ring width of that particular plant. The widths then would be expressed as a percentage of the average width. Production of a site should then be expressed as a percentage of the site's average annual production. This method of converting production was done by Sneva and Hyder (1962) and the converted values are referred to as yield indices. Yield indices for range sites from which the shrubs were collected are then plotted against the standardized ring widths. The sampling could be continued until the standard error is reduced to the satisfaction of the resource manager. On big sagebrush sites approximately $50 \mathrm{ring}$ widths were needed to reduce the standard error to $10 \%$ of the average production. Once a sufficient number of sites have been sampled, a single regression equation may be computed to obtain a production estimation equation for that particular shrub and within the area sampled. This would be meaningful only for plants such as big sagebrush that have sensitive ring widths.

Ring widths on species such as big sagebrush that represent annual growth increments appear to relect annual fluctuations in production. Ring widths for those chenopod species such as winterfat and shadscale may not always represent annual growth increments but they do reflect the productivity of each site. These ring widths can be used to determine average annual productivity.
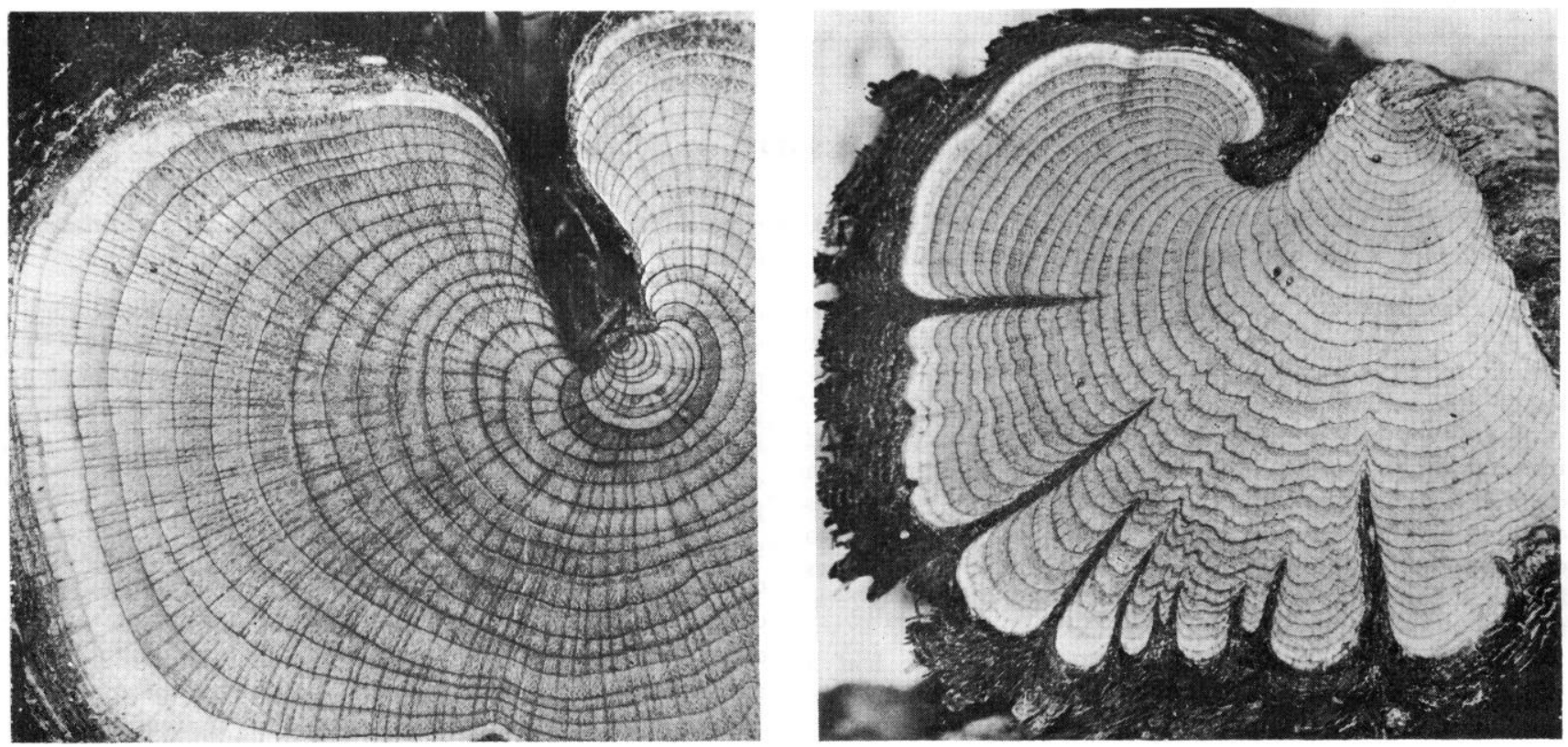

FIG. 2. Comparison of estimated production and actual production based on big sagebrush ring widths in the big sagebrush/galleta association. Left-Average ring width $=.73 \mathrm{~mm}$, actual production $=195 \mathrm{lb}$. $/$ acre, and estimated production $=214 \mathrm{lb}$. $/$ acre. Right-Average ring width $=.41 \mathrm{~mm}$, actual production $=95 \mathrm{lb} . /$ acre, and estimated production $=89 \mathrm{lb} . / \mathrm{acre}$. 
The past average estimated production for a site with big sagebrush or other species with sensitive growth ring series could be determined as far back in time as there are annual rings of the sample shrub. This offers an excellent opportunity for obtaining 5,10 , or 15 year average production for a particular site. For a shrub to be useful in estimating yield, unless it occurs as a pure stand, its period of growth must coincide with those species that contribute to all or most of the production within the association.

\section{Literature Cited}

Anonymous. 1968. Guides for calculating available waterholding capacity. Soil Conserv. Serv., U.S. Dep. Agr., Berkeley, Calif. Tech. Note No. 15. 1 p.

Blaisdell, J. P. 1958. Seasonal development and yield of native plants on the upper Snake River and their relationship to certain climate factors. U.S. Dep. Agr. Tech. Bull. 1190. $30 \mathrm{p}$.

Bouyoucos, G. J. 1936. Directions for making mechanical analysis of soils by the hydrometer method. Soil Sci. 42: 225-230.

Carmean, W. H. 1954. Site quality for douglas-fir in southwestern Washington and its relationships to precipitation, elevation, and physical soil properties. Soil Sci. Soc. Amer. Pro. 18:330-334.

DieHert, R. A. 1938. The morphology of Artemisia tridentata. Nutt. Lloydia 1:3-74.

Dixon, W. J. 1970. Stepwise regression, BMD Biomedical Computer Programs, Univ. of Calif. Publications in Automatic Computation. p. 233-257.

Doolitrte, W. I. 1957. Site index of scarlet and black oak in relation to southern Appalachian soil and topography. Forest Sci. 3:114-124.

Eames, A. J., and MacDaniels, L. H. 1925. An introduction to plant anatomy. McGraw-Hill Book Co., New York. $364 \mathrm{p}$.

Ferguson, C. W. 1964. Annual rings in big sagebrush. Papers of the Laboratory of Tree-Ring Research No. 1. The Univ. of Ariz. Press, New York. 95 p.

Goebel, C. J., Leonakd Debano, and Russel D. Lloyd. 1958. A new method of determining forage cover and production on desert shrub vegetation. J. Range Manage. 11:244-246.

Hulett, G. K., and G. W. Tomanek. 1969. Forage production on a clay upland range site in western Kansas. J. Range Manage. 22:270-276.

Hunt, Charles B. 1967. Physiography of the United States. W. H. Freeman and Co., San Francisco. 430 p.

Kinsinger, F. R., AND G. S. Strickler. 1961. Correlation of production with growth and ground cover of whitesage. J. Range Manage. 29:161-166.

Mason, L. R., AND S. S. Hutchings. 1967. Estimating foliage yields on Utah juniper from measurements of crown diameter. J. Range Manage. 20:161-166.

Medin, D. E. 1960. Physical site factors influencing annual production of true mountain mahogany (Cercocarpus montanus). Ecology 41:454-460.

MCGinNiEs, W. J. 1967. Correlation between annual rings of woody plants and herbage production. J. Range Manage. 20:42-45.

SNeVA, F. A., ANd D. N. HYder. 1962. Estimating herbage production on semi arid ranges in the Intermountain region. J. Range Manage. 15:88-93.

TowER, J. 1970. Vegetation stagnation in three-phase big game exclosures and its effect in determining forage utilization. M. S. Thesis; (unpublished). 65 p. 